\section{Global Value Chains, Business Networks, Strategy, and International Business: \\ Convergences}

\author{
John Humphrey ${ }^{1}$ \\ ${ }^{1}$ University of Sussex Business School, Brighton BN1 9SL, UK \\ Emanuela Todeva ${ }^{2}$ \\ ${ }^{2}$ St. Mary's University Twickenham London, The School of Management \\ and Social Sciences (MSS), Twickenham TW1 4SX, UK \\ Eduardo Armando ${ }^{3}$ \\ ${ }^{3}$ FIA Business School, ProCED Graduate Programs, Sao Paulo, S.P., Brazil \\ Ernesto Giglio ${ }^{4}$ \\ ${ }^{4}$ UNIP - Universidade Paulista, Masters Program \\ in Business, Sao Paulo, S.P., Brazil
}

\begin{abstract}
Purpose - The purpose of this paper is to clarify the distinction between Global Value Chains and selected strands of the business literature: business networks, strategy, and international business. These four research areas have starting questions that are often different and the audiences they address also differ. There have been attempts to establish links across these theories, but these are exceptions rather than the rule.
\end{abstract}

Design/methodology/approach - The basic principles and concepts of the four areas are identified. The results are used to develop a summary matrix of the approaches. The methodological path is inductive and inferential, as the task involves searching for similarities, complementarities, and overlaps across the four social science disciplines.

Findings - The literature of the studied fields overlaps on the issues they are trying to understand, even if they do not use identical terminology. The four areas advocate the same principle in understanding the organizational field: complexity. Firms are triggered to enter into exchange with other companies.

Originality/value - The theoretical contribution of this article is based on the idea that although the four research fields - GVC, Business Networks, Strategy, and International Business - advance independently from each other, common origins can be observed, allowing for a set of common propositions.

Keywords - Convergence, Global Value Chains, Business Networks, Strategy, International Business
Received on

$01 / 31 / 2018$

Approved on

$01 / 19 / 219$

Responsible editor:

Prof. Dr. João Maurício

Boaventura

\section{Evaluation process:}

Double Blind Review 


\section{Introduction}

Over the past three decades, global trade has grown and many new exporting countries, particularly in Asia, have been incorporated into the global economy. This growth has been accompanied by two important structural transformations. The first is the expansion of what Baldwin and Lopez-Gonzalez (2015) call supply-chain trade. Production has become more fragmented and the share of trade in finished products declined in the 1990s and the first decade of the $21^{\text {st }}$ century, while the share of trade in parts has increased (Baldwin \& LopezGonzalez, 2015). Second, even in sectors in which the activity of trading final products continues to dominate (for example, food, clothing, and shoes), the shift of production to developing and emerging economies has been accompanied by increased outsourcing and the role of firms specializing in design, marketing, and retail in structuring international trade. This trend has been described with terms such as "manufacturers without factories" (Gereffi, 1999, p. 46) and "factoryless goods producing firms" (Bernard \& Fort, 2015, p. 518).

Various theoretical approaches have attempted to understand these changes in terms of what they imply for both businesses and countries. The Global Value Chain (GVC) literature emerged as an attempt to understand these questions and identify their implications for developing countries. Equally, however, some strands of the business and management literature, notably the research on business networks, strategy, and international business, have addressed these issues. For example, the international business literature has used the concept of the "global factory" to describe how multinational firms have integrated production activities in Asia into their global strategies and what the consequences might be for the newly-integrated economies (Buckley, 2009).

These differing approaches have much in common. They are all concerned with fragmentation across borders (offshoring); fragmentation across businesses (outsourcing); and strategies for coordinating in the presence of fragmentation. Equally, they tend to draw on similar theoretical foundations, including transaction cost economics and knowledgebased and resource-based theories of the firm, and are concerned with how firms try to remain competitive in the global economy.

Nevertheless, the four research areas do not engage with each other as much as they should. Their starting questions are often different, as recent research has recognized (Strange \& Humphrey, 2018), and the audiences they address also differ. It is certainly true that there have been attempts to establish links across the theories, but these are exceptions rather than the rule. For this reason, this special issue of the RBGN has been devoted to the interface between GVC theory and three strands of the business literature that have also developed theory in the areas of globalization, competitiveness, and how businesses manage links with other firms. Thus, this collection of papers is a further attempt to promote dialogue and develop theory in these four research areas.

This overview frames the papers in the special issue through an analysis of the areas of interaction between the four themes: GVCs, business networks, strategy, and international business. In both the special issue and this paper, in general terms, the following questions are addressed: (1) What is the intersection of the literature on GVCs, strategy, business networks, and international business, and where has conceptual clarity and consensus already emerged? (2) In what ways might emergent research themes - for example, the circular economy, multistakeholder governance, and internationalization of knowledge and technology - use common knowledge across the four areas as an analytical tool to sharpen the understanding of these phenomena? (3) How might GVC analysis in issues such as innovation make effective use of concepts developed by business networks, strategy, and international business literature? 
Specifically, in this paper, we focus on answering the question that follows: What is the distinction between the GVC literature and the selected strands of the business literature, i.e. on business networks, strategy, and international business? Although there is a variety of business literature, we chose only these three strands for consideration. By answering this question and developing a theoretical synthesis, the basic principles and concepts of the four areas are identified. The results are used to develop a summary matrix of the approaches (Tables 1 and 2).

The paper is divided into four sections. The following section explains the logic behind the theoretical development. The main contribution of the paper lies in evidencing the convergences between the four fields studied, showing what they aim to explain, the scope of analysis of each field, as well as identifying the most investigated topics. We also make a methodological contribution by unveiling aspects that are common to the four fields.

Section three, the literature review, examines the most frequently referenced articles relating to each of the four approaches and the attempts to link them. The section concludes with a table that provides an interdisciplinary synthesis covering each of the approaches investigated.

The fourth section presents the theoretical outcomes of this article, its foundations, justifications, internal logic, theoretical coherence, and explanatory competence, which are compared with other efforts. The conclusion revisits the initial questions, presents the results, comments on the limitations of the theoretical enquiry, and examines the contributions of the article.

\section{Logic behind the Theoretical Development}

When writing a theoretical article it is important to explain the starting points of the analysis and the principles used for a critical review of the literature. Our methodological path is inductive and inferential, as the task involves searching for similarities, complementarities, and overlaps across the four social science disciplines referred to above.

The inductive classification is the result of searching for evidence and the convergence of indicators among the four research fields, presenting conclusions on the overlaps and similarities for analysis and the treatment of empirical observations. The inferential approach comes from bringing together ideas encapsulated in the concepts of the four academic disciplines, based on the content put forward by the relevant literature. For example, the concepts of dynamic competencies in the strategy field and social capital in relation to business networks show significant conceptual similarity. From the conceptual definitions, it is possible to infer that both categories refer to the creation of resources in a collective action and through learning feedback loops, therefore no existing actors, persons, or organizations act in isolation.

In order to apply this inferential approach systematically, we adopted a scientific categorization framework based on the paradigmatic theory raised by Kuhn (1962) and Popper and Hansen (2014) for the analysis of distinctive scientific fields. This framework is composed of eight categories that describe the contributions from each scientific discipline. These eight categories enable a systematic comparison across an interdisciplinary field:

- What are the dominant assumptions? This is an enquiry into basic assumptions that are accepted without discussion by the scientific community. For example, in both GVC and network theory it is assumed that the human being is social and needs to live in a group. Assumptions give direction to scientific enquiry and facilitate researchers in identifying the objects of their enquiry and the direction of argumentation, asking questions that are different from their assumptions.

- What are the dominant theories? Particularly in relation to other 
social theories such as economics, sociology, psychology, anthropology, or communications. For example, game theory applies to both economics and strategy. Dominant theories already cut across multidisciplinary social enquiries and bring with them a portfolio of research questions.

- What are the variants of contemporary theories? - The current development of basic theoretical frameworks and explanatory models within a discipline. For example, within network theory are hypotheses relating to social capital, governance, and group management. The proliferation of theoretical frameworks within an academic discipline as a field of enquiry shows new emergent discourses that give rise to new concepts and methodological tools.

- What is the phenomenon to be explained? - Refers to the object of analysis in an academic field of enquiry. For example, within networks one of the core investigative concepts is the structure of ties. The definition of the phenomenon that constitutes the objects of scientific enquiry influences much of the following methodologies and scientific practices.

- What is the scope of analysis? - Indicates the level of enquiry, whether the scope is people, groups, organizations, regions, states, or nations. For example, within networks, there are three distinctive levels of analysis - the actors, the relationships, and the whole network. The same analytical reasoning can be applied to the GVC field. Some disciplines and scientific fields of enquiry are broader in scope, connect multiple theories, and examine multiple objects of enquiry.

- What are the most frequent search topics? - Concerned with specific investigative categories and whether they refer to behaviors, processes, decisions, relationships, cost analysis, modes of production and sales, modes of competition, the analysis of social groups, or other core concepts. For example, core concepts and investigative questions related to networks include structure, relationships, strategies, results, and benefits.

- What is the dominant mode of knowledge construction? - These could vary from (1) a logical transition from observational facts to the construction of a theory; or (2) a transition from theoretical constructs to empirical testing in the field. It may be argued that the field of strategy predominantly uses the path from theory to practice and the field of networks the path from practice to theory. Scientists in each discipline develop certain preferences towards one or another methodology for knowledge construction.

- What are the dominant research techniques? - These could vary between questionnaires, interviews, follow-up monitoring, secondary data, big data, or focus group discussions. Examples of empirical techniques for data collection for networks include interviews and questionnaires, along with the snowball sampling technique, which are the dominant methods.

These categories enabled us to compare across different scientific fields of enquiry and search for common grounds in order to work towards a theoretical synthesis. We searched for the most cited authors within the four fields and selected information on the main contributions of their works and those of their followers. We used Scopus to select the most cited authors and completed the selection of publications as the intersection between the key expression search (GVC, Strategy, Networks, and International Business) with the author search. We selected the 10 most cited articles and analyzed the content of 
their theoretical statements. From this, we derived the categorization of the disciplinary frameworks.

\section{Literature Review}

The characteristics of present society are simultaneity, complexity, connectivity, interdependence, and plurality of power (Castells, 1996; Deleuze \& Guattari, 2004; Morin, 1990). Many of these characteristics are not substantiated by facts and evidence, but they are discussed in a number of theoretical and paradigmatic frameworks.

In science, these characteristics result in increasingly intense multidisciplinary movements, conjunctions, and overlaps where before there was focus and distinction. For example: What area of science deals with the planet sustainability phenomena? Currently, it is possible to find disciplines in universities and congresses that combine segments of biology, geology, social sciences, engineering, and medical sciences. Thus, the effort to integrate the four aforementioned areas of knowledge in the social sciences - GVCs, strategy, business networks, and international business - makes sense. We start with efforts to integrate the four areas of knowledge and then present the literature on each of these. The final part of this section provides Table 1 , with a synthesis of the literature using the logic presented in section 2 .

\section{I Efforts to integrate the four areas}

A key step in the investigation was to find publications that tried to integrate the four fields addressed in this article - GVCs, strategy, business networks, and international business. Gereff, Humphrey, and Sturgeon (2005) try to integrate the strategy and GVC fields using a governance framework for business-to-business linkages. While it should be noted that the approach suggested by these authors incorporates resource-based views of the firm alongside knowledge-based and transaction cost approaches, it has been criticized for ignoring intra-industry variations in governance across firms, time, and locations (Sako \& Zylberberg, 2017). Sako and Zylberberg (2017) propose refinements that involve injecting management theories into GVC research, presenting a modified framework for corporate strategy in GVCs.

There have been other attempts to link GVC and business theory (De Marchi, Di Maria, \& Ponte, 2014; Humphrey, 2014; Lema, 2014; Narula \& Wahed, 2017), along with efforts to connect GVC and innovation theory (De Marchi, Giuliani, \& Rabellotti, 2017; Keijser \& Iizuka, 2018; Pietrobelli \& Staritz, 2018; Tajoli $\&$ Felice, 2018), but there are differences in the two approaches. Whereas business theories, particularly the strategy approach, emphasize agency, this is a weak point in the GVC literature, which puts greater emphasis on structure and constraints on action. As a result, business theories (for example, internalization theory) focus on the multinational firm and its strategic choices, while GVC theory is more concerned with the characteristics and choices typical of sectors as a whole.

There are also efforts to bring together GVC and network principles in the public policy field (Todeva \& Rakhmatullin, 2016a). International agencies such as the Organization for Economic Cooperation and Development (OECD), the World Trade Organization (WTO), and the World Bank have recognized and promoted the importance of increased participation in the global economy through GVC linkages for developing countries, pointing to positive impacts on homegrown businesses in terms of enhancing competitiveness (OECD, WTO, \& World Bank Group, 2014). The argument here is that the disaggregation of production into separate stages allows firms to gain easier access to the globalization ladder and ascend it as their capabilities improve. In this view, GVCs encourage such upward movement by rewarding skills, learning, and innovation, as well as through learning from value chain partners. In other words, better positions and higher rents are assured for companies in developing countries if they enter GVCs. 
This view is very controversial. Critics highlight the risks faced by domestic firms from developing countries through exposure to a "race to the bottom" as new supply locations are integrated into the global economy (Kaplinsky, 2000; United Nations Industrial Development Organization [UNIDO], 2009; United Nations Conference on Trade and Development [UNCTAD], 2013). Furthermore, it has been argued that lead firms may actively prevent their suppliers from upgrading, instead tending to outsource activities where there is, or where they can create, competition among suppliers, making it difficult to capture rents (Pietrobelli \& Staritz, 2018).

The discussion about upgrading also reveals a structure/agency distinction, although this time within GVC approaches. While Pietrobelli and Staritz (2018) refer to individual firms, there is a strong public policy approach in the GVC literature that views upgrading as interesting if insertion into the global economy improves incomes and livelihoods in developing countries. For Kaplinsky, Morris, and Readman (2002, p. 1160), "upgrading is an essential aspect of ensuring a sustainable trajectory to economic development".

The discussion about the different ways in which developing country businesses can benefit from participation in GVCs frequently links to the business network literature, and particularly so with respect to localities and clusters, but with a focus on how external linkages shape local contexts. Humphrey and Schmitz (2002) discuss the linkages between the cluster and value chain literatures. The issue is that the GVC approach prioritizes vertical, transnational links as sources of knowledge, whereas the cluster approach emphasizes horizontal links between firms and local institutions. Both strands of the literature provide a partial picture, but it must be noted that there has been some interesting work on clusters and their links to the global economy (Gereffi \& Lee, 2016; Lorenzen \& Mudambi, 2013; Morrison, Rabellotti, \& Zirulia, 2012), and analysis of cross-national links between different clusters (Nadvi \& Halder, 2005; MeyerStamer, Maggi, \& Seibel, 2004). Some GVC papers emphasize the role of locality (Crescenzi, Pietrobelli, \& Rabellotti, 2014; Nadvi, 2008; Sturgeon, Van Biesebroeck, \& Gereffi, 2008). There is more recently published research as well, but in both strands of the literature, since only the three most cited articles were selected, there is a bias towards older publications.

This is probably the strongest argument for bringing together different literatures, although as they begin with different questions and assumptions, this is not an easy task. International institutions have acknowledged that GVCs constitute a complex network of investment and trade flows and that multinational enterprises (MNEs) drive all vehicles for integrating countries and domestic firms into GVCs, including foreign market operations of MNEs, domestic firm exports, and redirecting GVC flows through new regions, clusters, and countries that offer new business opportunities (UNCTAD, 2013).

Positions in the expanded middle of value chains, through the market and vertical integration within MNEs, have become more popular in several industries where the business models of firms incorporate a nexus of foreign ownership and international business networks of operations (Todeva, 2006; Todeva \& Rakhmatullin, 2016b).

To conclude, there is evidence of complementarity among the four fields; however, according to our understanding, an organizational effort is necessary based on the principles of the theory of knowledge, as described in item 2. Next, we present the ten most cited articles for each of the areas of the literature in order to perform this task.

\subsection{GVC literature}

The field of study entitled Global Value Chain is increasingly important within the organizational and management field, because business expands beyond its local business boundaries - whether in production, marketing, or service delivery - into global chains (Kaplinsky 
\& Morris, 2002). In order to create models and theories concerning global value chains, considering the wide scope that encompasses different countries, regions, cultures, and sociodemographic profiles, the area is characterized as being interdisciplinary. According to the organizational objects under analysis, it may be necessary to link models and theories involving global strategies, consumer behavior, social networks, culture, value, and ethics in consumption, to name just a few.

A search for the 10 most cited articles on the Scopus platform, using the expression "global value chain" with a filter in the title, resulted in the following list: 1. Gereffi et al. (2005), on governance in GVCs; 2. Frohlich and Westbrook (2001), regarding the integration of global strategies; 3. Humphrey and Schmitz (2002), on GVCs and industrial clusters; 4. Rugman and Verbeke (2004), who show the differences between the internalization theory approach and the GVC approach (the questions and assumptions are different rather than similar); 5. Manuj and Mentzer (2008), on rich strategies in the global supply chain; 6. Horvath (2001), who write about collaboration in global chains; 7. Andersen and Skjoett-Larsen (2009), who focus on social responsibility in global chains; 8. Barrientos, Gereffi, and Rossi (2011), on new paradigms in production networks; 9. Gereffi and Lee (2012), on the growing importance of GVCs; and, finally, 10. Saliola and Zanfei (2009), regarding GVCs and knowledge transfer. Here, it is important to point out that although the criteria we used were exactly the same for the four research areas, there is a problem with the widespread and differential use of the term value chain. As an example, in Frohlich and Westbrook's (2001) article, although highly cited under the adopted criteria, the term value chain only appears once, in one of the items listed in the references.

The list illustrates that most of these articles were written in the current century, when the subject matter became important for business and academia. The second observation concerns the emphasis placed by these articles on strategies and networks. The data indicate that the integration effort can be observed from the early stages of the academic discourse on GVCs, and the aim of this article to provide a systematic synthesis is justified and consistent with the academic production.

Reading the key parts of these articles, i.e., the abstract, introduction, and basic concept, enabled us to develop a representation of the GVC as a scientific field, as described in Table 1.

The GVC literature converges around a common definition of their "object of analysis" in the following way: "Value chains contain fragmented, modularized activities across inputoutput markets, and describe interconnected industrial processes. They are typically presented as the sequence of: product (service) design, supply with input materials, production, marketing, distribution, post-sales services to consumers, and disposal after use" (Todeva \& Rakhmatullin, 2016a). As such, the GVC literature encompasses much of the organization and management knowledge on interconnected business activities, and renders itself closer to the strategy literature, where the concept of connected and dynamic capabilities receives a more thorough treatment.

\section{$3 \cdot 3$ Strategy literature}

The literature on entrepreneurship and management began with the work of Penrose (1959), whose ideas subsequently gave rise to the so-called Resource-Based View (Barney, 1991). The original ideas encapsulate a process of inbound and outbound resource flows. Porter (1985) adds to this analytical tool the notion of value chains and value systems, which details the resources and capabilities that can be owned and developed by companies and the internal and external connectivity of resource and activity flows. One addition is the representation of activities that add value to the production chain (Todeva \& Rakhmatullin, 2016a).

A search was run in the Scopus platform, using the expression "strategy" to find articles. 
Additionally, the search was run with a filter in the title, to select articles that had the word "strategy" - or "strategies" - in their title. As the expression "strategy" is popular in many areas of knowledge, in order to have a consistent selection of articles, it was necessary to add the focus on business in the platform's range of possibilities. The 10 most cited articles on the Scopus platform with the aforementioned filters resulted in the following list: 1. Dyer and Singh (1998), who examine cooperation as a strategy for organizations; 2. Grant (1991), on resource-based theory and strategy formulation; 3. Porter and Kramer (2006), on strategy, society, competitive advantage, and corporate social responsibility; 4. Hansen, Nohria, and Tierney (1999), in relation to knowledge management practices; 5 . Porter (2001), on strategy and the internet; 6 . Hoskisson, Eden, Lau, and Wright (2000), on strategy in emerging economies; 7. Mintzberg and Waters (1985), on strategy types (deliberate and emergent); 8. Teece (2010), regarding business models, business strategy, and innovation; 9. Porter (1991), on a dynamic theory of strategy; and 10. Frohlich and Westbrook (2001), on the international study of supply chain strategies. This shows a concentration of articles around the turn of the century.

Looking at the titles and abstracts, we can find some approaches regarding global chains (Frohlich \& Westbrook, 2001) and networks (Dyer \& Singh, 1998). Other publications, not in the top ten, also present these approaches. When discussing, for example, upgrading in GVCs, the notion of dynamic capabilities is implicit (Teece, Pisano, \& Shuen, 1997), allowing the company to evolve within the chains. It has been known for some time that capabilities required by a firm often depend upon its connection to networks and locations (Marshall, 1890), again showing the connection between strategy and networks.

Academics accept that relationships and information flows drive the learning that enables dynamic training. Resource and knowledge flows are linked to the location in which the company operates, as well as reacting to global competitive forces (Todeva, 2006). Often, subsidiaries of multinational companies are locally connected to clusters. Recently, it has been recognized in the literature that the relationship with the location should be considered within the strategy, even in the case of multinationals (Verbeke, Kano, \& Yuan, 2016). Clusters are ultimately dynamic business environments that concentrate one or a few capabilities on a regional basis (Todeva $\&$ Rakhmatullin, 2016a).

Reading the key sections of the articles, i.e., the abstract, introduction, and basic concept, enabled us to develop a representation of strategy as a scientific field, as described in Table 1.

Overall, the strategy literature extends scientific knowledge into the realm of how decisions and strategic choices lead to inter-firm connectivity, which further mobilizes network and cluster capabilities for enhanced firm performance. The literature also acknowledges that value chains are determined by production technologies, manufacturing processes, and product/service markets. Large firms are able to control their own value chains and coordinate value-added activities by managing both their own operations and supplier networks, alliance partnerships, and governance platforms for outsourcing and inbound/outbound logistics, leading to a dynamic value chain configuration process (Todeva, 2006; Todeva \& Rakhmatullin, 2016a).

\subsection{Business networks literature}

The study of networks is increasingly important in the organizational field as a result of: (a) the growth of collective phenomena in business and society; (b) recognition by the scientific community that the network format is not a fad, but rather an alternative course of action for organizations; (c) the growing interest of researchers regarding the subject of networks (Nohria, 1992).

Since its acceptance and legitimacy as a scientific field in the 1990s, the academic and 
managerial publications on the topic of networks have become broad and diffuse, with no dominant paradigm (Oliver \& Ebers, 1998).

There are various concepts of networks that use principles from a variety of areas, such as economics, biology, sociology, anthropology, psychology, and communications. The resulting definitions can value economic aspects (Williamson, 1979) or focus on rational and strategic actions (Gulati, 1998), social characteristics (DiMaggio \& Powell, 1991), political processes (Börzel, 1998), structural relationships (Burt, 1982; Uzzi, 1997), and networks as governance (Grandori, 2006).

The search for the 10 most cited articles in the Scopus platform using the expressions "networks", "business networks", and "concept of networks", without a time filter, resulted in the following list: 1. Freeman (1978), who wrote about centrality in social networks; 2 . Nahapiet and Ghoshal (1998), concerning social capital and organizational advantage; 3. Portes (1998), who focused on social capital; 4. Dyer and Singh (1998), regarding relationship and competitive advantage; 5. Uzzi (1997), in relation to social structure and competition; 6. Powell, Koput, and Smith-Doerr (1996), concerning collaboration and innovation; 7. Adler and Kwon (2002), regarding social capital; 8. Uzzi (1996), in relation to embeddedness and economic performance; 9. Tsai and Ghoshal (1998), on the topic of social capital and value creation; and 10. Gulati (1998), regarding alliances and networks.

From analyzing the list, it is evident that most articles were published in the 1990s, just as the field of networks was becoming legitimate in academic and business circles following the changing forms of global competition. The second observation relates to the dominance of the expression "social capital" in the whole list, although it appears most in an article on structural analysis.

The field of networks remains deeply embedded in organizational theory and thus does not show a specific interest in relation to the globalization problem or the issues that emerge with cross-country and cross-cultural network interactions, which are well depicted in the international business literature.

Although we did not find any dominant network theory, it is possible to infer that statements about structural analysis and relationship analysis are the most frequently used in the research. The key words are "interdependence", "complexity", and "exchanges". The first two (interdependence and complexity) also appear when analyzing the GVC field.

Reading the key parts of these articles, i.e., the abstract, introduction, and basic concept, enabled us to develop a representation of networks as a scientific field, as described in Table 1.

\subsection{International business literature}

The transition from value chains to global value chains has not taken place smoothly. Although the international business field has explored a broad range of modes of firm internationalization and strategic alliance formation, it has, until recently, tended to focus on the market-hierarchy dichotomy rather than on intermediate forms. Most of the research has focused on modes of internationalization and foreign market entry, utilizing the assumption of firms as independent strategic agents, autonomous from input and output markets (Dunning, 1980, 1988, 1998; Johanson \& Vahlne, 1977). A significant number of articles have focused on international strategic alliances and partnerships, joint ventures, and mergers and acquisitions without exploring the distribution of value added within these inter-firm relationships. The international business strategy literature explores motives for and drivers of strategic alliances and partnerships, with a focus on performance rather than value added. The discussion on knowledge and learning very often treats these concepts as assets and resources, rather than dynamic capabilities (Kogut \& Zander, 1992).

As a result, the strategic motives for and drivers of cross-border operations are often explained through a value capture, rather than 
value-added argument, and chains are mainly examined in terms of inter-firm relationships. The multinational enterprise as an object of analysis in the international business literature is discussed in terms of ownership and control and through the governance lenses, or the economic lenses of intra-firm trade. These arguments rarely look at intra-firm and inter-firm trade as a global chain of intermediate products and a strategic portfolio of ultimate global owners (parents) and their subsidiaries, but rather as the internalization of value added. This is one of the main reasons why the literature on GVCs and international business exhibits crossovers and cross-citation.

The search for the 10 most cited articles in the Scopus platform, using the expressions "international business", without a time filter, resulted in the following list: 1. Johanson and Vahlne (1977), on the internationalization process of firms through knowledge development and increasing foreign market commitments; 2 . Kogut and Singh (1988), on the effect of national culture on the choice of entry mode; 3. Kogut and Zander (1993), whose work examines knowledge of the firm and the evolutionary theory of the multinational corporation; 4. Dunning (1988), regarding the eclectic paradigm of international production; 5. Dunning (1995), on the eclectic paradigm in an age of alliance capitalism; 6 . Oviatt and McDougall (1994), who offer a theory of new international ventures; 7. Hofstede (1983), regarding the cultural relativity of organizational practices and theories; 8 . Agarwal and Ramaswami (1992), on the choice of foreign-market entry mode; 9. Parkhe (1991), regarding inter-firm diversity, organizational learning, and longevity in global strategic alliances; and 10. Knight and Cavusgil (2004), on innovation, organizational capabilities, and the born-global firm.

Reading the abstracts, we can see that information, cooperation, and commitment are consistent expressions.

One rarely discussed issue is value added resulting from activities flows in and out of companies and regions through foreign trade and foreign investment linkages. This process is in the hands of MNEs and is affected by multiple global stakeholders.

\subsection{Synthesis of the literature}

Reading the key points of the selected articles, i.e., the abstract, introduction, and basic concept, enabled us to develop a representation of the four fields, as proposed, which is shown in Table 1. 
Table 1

The content of scientific categories across the literature on global value chains, strategy, networks, and international business

\begin{tabular}{|c|c|c|c|c|}
\hline \multirow[b]{2}{*}{ Category } & \multicolumn{4}{|c|}{ Synthesis in the literature field } \\
\hline & GVC & Strategy & Business Networks & $\begin{array}{c}\text { International } \\
\text { Business }\end{array}$ \\
\hline $\begin{array}{l}\text { Dominant } \\
\text { assumption }\end{array}$ & $\begin{array}{l}\text { No company is } \\
\text { self-sufficient, so } \\
\text { relationships matter. }\end{array}$ & $\begin{array}{l}\text { The performance of the } \\
\text { firm depends on the } \\
\text { capabilities it can develop. }\end{array}$ & $\begin{array}{l}\text { The complexity of the } \\
\text { contemporary organizational } \\
\text { field creates interdependence } \\
\text { and supports collective action } \\
\text { by enterprises. }\end{array}$ & $\begin{array}{c}\text { The internationalization } \\
\text { of firms is driven } \\
\text { by the comparative } \\
\text { advantage of host } \\
\text { countries, conditions of } \\
\text { the domestic market, } \\
\text { and global competitive } \\
\text { forces. }\end{array}$ \\
\hline $\begin{array}{l}\text { Dominant } \\
\text { theory }\end{array}$ & $\begin{array}{c}\text { All production } \\
\text { processes are connected, } \\
\text { drawing on global } \\
\text { channels of input and } \\
\text { output markets. }\end{array}$ & $\begin{array}{l}\text { Dynamic capabilities, } \\
\text { meaning that capacities } \\
\text { are not static, but } \\
\text { instead dynamic; that is, } \\
\text { they are influenced by } \\
\text { company strategy. }\end{array}$ & $\begin{array}{l}\text { The relationships } \\
\text { (exchanges) created give } \\
\text { access to resources. }\end{array}$ & $\begin{array}{l}\text { MNEs, with } \\
\text { their motives for } \\
\text { internationalization, } \\
\text { are mainly driven } \\
\text { by performance } \\
\text { maximization. }\end{array}$ \\
\hline $\begin{array}{l}\text { Variants of } \\
\text { contemporary } \\
\text { theories }\end{array}$ & $\begin{array}{l}\text { Global capabilities; } \\
\text { network chain. }\end{array}$ & $\begin{array}{l}\text { Value systems; inter- } \\
\text { firm networks. }\end{array}$ & $\begin{array}{l}\text { Social capital; network } \\
\text { governance. }\end{array}$ & $\begin{array}{l}\text { Internationalization; } \\
\text { foreign market } \\
\text { entry; foreign direct } \\
\text { investment. } \\
\end{array}$ \\
\hline $\begin{array}{c}\text { The } \\
\text { phenomenon } \\
\text { to be } \\
\text { explained }\end{array}$ & $\begin{array}{l}\text { The global division of } \\
\text { labor and links between } \\
\text { firms. }\end{array}$ & $\begin{array}{l}\text { Connections between } \\
\text { business strategy, } \\
\text { local networks, } \\
\text { such as clusters, and } \\
\text { performance in GVCs. }\end{array}$ & $\begin{array}{l}\text { Collective action, } \\
\text { independent of the goals } \\
\text { to be achieved. }\end{array}$ & $\begin{array}{c}\text { Portfolio of } \\
\text { operations of MNEs } \\
\text { and the impact } \\
\text { of environmental } \\
\text { conditions. }\end{array}$ \\
\hline $\begin{array}{l}\text { The scope of } \\
\text { analysis }\end{array}$ & $\begin{array}{c}\text { The whole } \\
\text { organizational field. }\end{array}$ & $\begin{array}{l}\text { Capabilities that firms } \\
\text { develop or obtain } \\
\text { within networks } \\
\text { to which they are } \\
\text { connected. }\end{array}$ & $\begin{array}{l}\text { People or organizations; } \\
\text { one actor in the network, } \\
\text { two actors (dyadic), } \\
\text { many actors (the whole } \\
\text { network). }\end{array}$ & $\begin{array}{l}\text { MNEs, subsidiaries, } \\
\text { and portfolio of } \\
\text { operations. }\end{array}$ \\
\hline $\begin{array}{l}\text { The most } \\
\text { frequent } \\
\text { search topics }\end{array}$ & $\begin{array}{l}\text { Process, global } \\
\text { production models, } \\
\text { structure of channels. }\end{array}$ & $\begin{array}{c}\text { Strategic decisions, } \\
\text { capability development, } \\
\text { acquisition of resources } \\
\text { in networks. }\end{array}$ & $\begin{array}{l}\text { Social capital, solutions } \\
\text { around resource } \\
\text { dependence, strategies, } \\
\text { and social variables. }\end{array}$ & $\begin{array}{l}\text { Motives for and drivers } \\
\text { of internationalization, } \\
\text { the impact of culture, } \\
\text { foreign market entry, } \\
\text { and market knowledge. }\end{array}$ \\
\hline $\begin{array}{l}\text { Dominant } \\
\text { mode of } \\
\text { knowledge } \\
\text { construction }\end{array}$ & $\begin{array}{c}\text { Moving from a } \\
\text { situation of case } \\
\text { description to } \\
\text { generalizations and } \\
\text { theory formation. Tests } \\
\text { of models have already } \\
\text { been carried out. }\end{array}$ & $\begin{array}{l}\text { Empirical, analyzing } \\
\text { cases of success and } \\
\text { failure. }\end{array}$ & $\begin{array}{l}\text { No dominant theoretical } \\
\text { position; case studies } \\
\text { with some generalizations } \\
\text { accepted by academic } \\
\text { community. }\end{array}$ & $\begin{array}{l}\text { Comparative case } \\
\text { studies. }\end{array}$ \\
\hline $\begin{array}{l}\text { Dominant } \\
\text { research } \\
\text { techniques }\end{array}$ & $\begin{array}{l}\text { Process follow-up, } \\
\text { quantitative and } \\
\text { qualitative studies. }\end{array}$ & $\begin{array}{l}\text { Interviews, application } \\
\text { of questionnaires, } \\
\text { model tests. }\end{array}$ & $\begin{array}{c}\text { Qualitative, with } \\
\text { interviews; } \\
\text { quantitative, with } \\
\text { structural analysis of } \\
\text { connections and positions; } \\
\text { growing importance of big } \\
\text { data analysis. }\end{array}$ & $\begin{array}{l}\text { Global surveys, } \\
\text { econometric models, } \\
\text { secondary data, and } \\
\text { business statistics. }\end{array}$ \\
\hline
\end{tabular}




\section{The Convergence of the Four Categories}

Having completed the analysis within each field, the next step was to search for coincident occurrences across all four fields. The search for "GVC-Network-Strategy-International Business" in the title generated no results. Next, we ran the search in pairs of these words, with a third one as a general filter. Thus, as an example, we looked for "GVC" and "Network" in the title and "Strategy" as a general filter. In the next paragraphs, we describe and briefly comment on the results of these searches.

When running the search in pairs, keeping "GVC" and "Strategy" in the title and using the expression "Network" as a general filter, 12 documents were found; one of these was the work of Brennan and Rakhmatullin (2017) examining the role of global value chains in the context of smart specialization strategies.

Running the search using "GVC" and "Network" in the title and "Strategy" as a general filter resulted in 18 documents. Three are of interest: Horner (2017), who discussed actors' roles in GVCs; De Marchi et al. (2014), regarding the management of global networks; and Parrilli, Nadvi, and Yeung (2013), who focused on comparing local and regional development in the global value chain, production networks, and innovation networks.

A search using the words "Network" and "Strategy" in the title and "GVC" in the general filter yielded eight publications. Two are of interest for this paper: Rudberg and Olhager (2003), who combine manufacturing networks and supply chains in a strategy perspective; and Chang (2012), whose work concerns strategy, network structure, channels, and global leaders.

Running the search using "International Business" and "Strategy" resulted in 110 documents. Adding a third expression such as GVC or Network resulted in no documents.

The reason why no articles arise when searching using the three (and, of course, four) keywords remains unanswered. It is intriguing because when the search is conducted in pairs, there are approximations that can be juxtaposed. As an example, when running the search in pairs, convergences appear with the keywords "complexity", "interdependence", "exchange”, and "new form of competition" (global and between groups). For other terms, when searching using three words instead of two, no results (articles) came up. However, when we read the articles that resulted from the search in pairs we saw that their content was convergent with the other themes (words) searched. Thus, although the articles' research was convergent, maybe due to different terminology, they did not appear in some searches. Clearly, these literatures overlap on the issues they are trying to understand, even if they do not use identical terminology.

For example, apparent complexity is used in the four areas, relating to uncertainty, unpredictability, multiple specialty requirements, mutability of phenomena, and the behavior of people in the organizational field. In this context, interdependence arises. As Rusbult and Arriaga (1997) note, interdependence means that no person or organization holds all the resources necessary to carry out tasks; thus, associations with other parties are required. Recognition of interdependence on the part of entrepreneurs leads to the necessary exchange of resources. The exchange results from understanding a complex organizational field and the condition of interdependence.

Thus, the four areas advocate the same principle in understanding the organizational field: complexity. Mirroring the interdependence of people, firms are driven to enter into exchanges with other companies. The starting action, therefore, is the collective system of exchange: to seek some protection against a complex environment and solve resource dependencies. An analysis of the statements presented in the tables raises the possibility of inferring the convergences between the four fields. These are presented in Table 2. One example of our 
inferential reasoning is the following: in the GVC field, a central research topic is described by the word "integration"; in the area of strategy, it is "partnership"; while in the area of networks, it is "commitment". The concept related to all three results from the same principle of needing others in order to complement resources. This point is placed as a dominant statement in Table 2 .

Table 2

The convergence between principles in the fields of GVCs, strategy, networks, and international business

\begin{tabular}{|c|c|}
\hline Category & Synthesis \\
\hline The Dominant Assumption & $\begin{array}{l}\text { Complex environment created interdependence, demanding cooperation and } \\
\text { exchange among organizations. }\end{array}$ \\
\hline The Dominant Theory & $\begin{array}{l}\text { Resource dependence. } \\
\text { To address dependence, networks and exchange are identified as resources. }\end{array}$ \\
\hline What is the phenomenon to be explained? & The modes and operations of exchange between actors. \\
\hline What is the scope of analysis? & $\begin{array}{l}\text { The relationships and behavior of individuals and/or organizations. } \\
\text { Organizational modes of exchange and competition. }\end{array}$ \\
\hline What are the most frequent search topics? & Exchange, relationships, value creation, and network strategy. \\
\hline Dominant mode of knowledge construction & $\begin{array}{l}\text { Empirical, with case studies to search for and deduce generalizations, even } \\
\text { recognizing the specificity of each network. }\end{array}$ \\
\hline Dominant research techniques & $\begin{array}{l}\text { Case studies, from conjunction variable modes, in research designs of causal, } \\
\text { corresponding, or systemic relationships. } \\
\text { Qualitative research with interviews; quantitative research with flow analysis, } \\
\text { structural analysis, and secondary data. }\end{array}$ \\
\hline
\end{tabular}

From this analysis and synthesis, we observe that there are some interactions between different strands of the literature. As examples in the synthesis, the idea of the complex environment comes from strategy, as does resource dependence. The concepts of exchange, actors, and relationships are present in the network literature. These, in addition to value creation and the influence of resources, are present in the GVC literature. However, such interactions between different literatures have been mostly between one another, and there are not enough for it to be systematic. Although we are aware that there is a long road ahead, this paper does advance in the direction of systematically studying the four fields of literature.

\section{Final comments}

In consideration of the theme of this special issue, this paper analyzed the interfaces between the four fields using the categories that define a scientific area. The result was that convergence appeared such that it can be asserted that the four fields may move towards integration. The interdisciplinary movement seems to be a scientific one that is coherent with the integration of social phenomena (such as the internet). The networked society, connected by new values, ethics, rituals, and social practices - including business practices - requires theories capable of dealing with the complexity, unpredictability, and global scope of these phenomena.

From the analysis of the most cited articles in the four fields investigated - GVCs, Strategy, Networks, and International Business - we find principles that are applicable to all. However, the analysis also showed that integration efforts are rare. One of the reasons, as interpreted based on the research experience of the authors, is that the positivist methodology, with its division and 
analysis of components, is still very strong and widespread within academia, making it difficult to find unity.

Our attention now returns to the questions posed in the introduction of this paper:

(1) What is the intersection in the literature on GVCs, strategy, business networks, and international business where conceptual clarity and consensus has already emerged? In this paper, we demonstrated the intersection in Table 2. While full clarity was not obtained, it does throw light on the convergences that exist in the literature, at least in the most cited papers in the Scopus database. In terms of consensus, although it is not explicit, we can see that the dominant assumption regarding the complex environment that created interdependence is consensual. Also consensual is the fact that such interdependence demands cooperation among organizations. There is conceptual clarity and consensus on the dominant theory as well, pointing to resource dependence (as shown in Table 2). All four fields try to explain modes and operations of exchange between actors. In terms of the scope of analysis, the most cited articles in all four fields focus on the relationships and behavior of individuals and organizations, and on organizational modes of exchange and competition. In all four fields, the most investigated topics are exchange, relationships, value creation, and network strategy. Also, in all four fields, the dominant mode of knowledge construction is empirical and in terms of research techniques, case studies are mostly used in all four using qualitative methods.

(2) In what ways might emergent research themes - for example, the circular economy, multi-stakeholder governance, and the internationalization of knowledge and technology - use common knowledge from the four areas as an analytical tool to sharpen our understanding of these phenomena? The convergences found, while they do not allow us to address these issues directly, may bring some light to these new research themes. The first point relates to the dominant assumption that, currently, environmental complexity is not diminishing; perhaps on the contrary, the world is becoming more and more complex, creating more and more interdependence, and demanding more and more cooperation and exchange among organizations. The increase in complexity derives from the three examples in the question: the circular economy, multi-stakeholder governance, and the internationalization of knowledge and technology. The circular economy makes the issue of resources more complex, probably leading to a revision of the concept. Multi-stakeholder governance will doubtless also lead to a revision of the concept of resources as well as their acquisition. These phenomena can likely be better explained and dealt with by the dominant theory in the four fields of literature: resource dependence. In fact, with regard to the circular economy, actors behave differently from how they used to. Multistakeholder governance brings more actors to the table, thus requiring more sophisticated forms of explaining their modes and operations of exchange, which the common knowledge of the four areas can probably do.

(3) How might GVC analysis in issues such as innovation make effective use of concepts developed by the business networks, strategy, and international business literature? As we can see in Tables 1 and 2, each field can take advantage of and effectively use the propositions and models from the other fields. As an example, the concept of network orchestration (Perks, Kowalkowski, Witell, \& Gustafsson, 2017) may be useful when investigating global chains in the supportive economy, using the GVC perspective.

The theoretical contribution of this article is based on the idea that although the four research fields - GVCs, Business Networks, Strategy, and International Business - advance independently from each other, common origins can be observed, thus enabling a set of common propositions. The starting point of the proposed integration is presented in Table 2 and one possible next step may be to refine these convergences, using clear wording in a way that can be understood and 
applied by researchers in any of the investigated fields. As with any intellectual effort, this one has its limitations. One of these that deserves mentioning relates to the selection of the articles. Although we used the same criteria for the four research areas, there is the possibility that an important article may have been left out of the selection. The opposite is also possible, as we may have included a paper that is not considered very important by the community of researchers, despite meeting the proposed criteria.

The article also makes a methodological contribution, putting forward the proposition that there are theoretical and methodological aspects that are common to the four fields and synthetizing them, thus allowing for replications, new conjectures, and the possibility of migrating research that was developed in one field to another. Thus, as an example, GVC research on the circular economy may be replicated or complemented by researchers who base their investigations on strategy or international business literature. One research opportunity that this study did not explore is examining in greater depth the commonalities and differences between the four areas. One concrete suggestion in this regard is to systematically explore the content of Table 1 .

There have, in fact, already been efforts to integrate the fields, namely the 2030 Agenda for Sustainable Development (United Nations, 2015). The principles on which some of these initiatives are based prioritize exchanges, relationships, and collective value creation. These words refer to collective endeavors, which are the converging focus of analysis in the four fields of GVCs, Business Networks, Strategy, and International Business.

\section{References}

Adler, P. S., \& Kwon, S.-W. (2002). Social capital: Prospects for a new concept. Academy of Management Review, 27(1), 17-40.

Agarwal, S., \& Ramaswami, S. (1992). Choice of foreign-market entry mode - impact of ownership, location and internalization factors. Journal of International Business Studies, 23(1), $1-27$.

Andersen, M., \& Skjoett-Larsen, T. (2009). Corporate social responsibility in global supply chains. Supply Chain Management: An International Journal, 14(2), 75-86.

Baldwin, R., \& Lopez-Gonzalez, J. (2015). Supply-chain trade: A portrait of global patterns and several testable hypotheses. The World Economy, 38(11), 1682-721.

Barney, J. B. (1991). Firm resources and sustained competitive advantage. Journal of Management, 17(1), 99-120.

Barrientos, S., Gereffi, G., \& Rossi, A. (2011). Economic and social upgrading in global production networks: A new paradigm for a changing world. International Labour Review, 150(3-4), 319-340.

Bernard, A. B., \& Fort, T. C. (2015). Factoryless goods producing firms. American Economic Review: Papers \& Proceedings, 105(5), 518-523.

Börzel, T. A. (1998). Organizing Babylon - On the different conceptions of policy networks. Public Administration, 76(2), 253-273.

Brennan, L., \& Rakhmatullin, R. (2017). Transnationalizing smart specialization strategy. In $S$. Radosevic, A. Curaj, R. Gheorghiu, L. Andreescu, \& I. Wade (Eds.). Advances in the theory and practice of smart specialization (pp. 249 - 268). London: Elsevier.

Buckley, P. J. (2009). The impact of the global factory on economic development. Journal of World Business, 44(2), 131-43.

Burt, R. S. (1982). Toward a structural theory of action network models of social structure, perception, and action. New York: Academic Press Inc.

Castells, M. (1996). The rise of networks society. Malden, MA: John Wiley \& Sons Ltd. 
Chang, Y. (2012). Strategy, structure and channel for global leaders of industrial service: A flow chart analysis of the expanded value network. International Journal of Services Technology and Management, 17(2-4), 138-162.

Crescenzi, R., Pietrobelli, C., \& Rabellotti, R. (2014). Innovation drivers, value chains and the geography of multinational corporations in Europe. Journal of Economic Geography, 14(6), 1053-1086.

De Marchi, V., Di Maria, E., \& Ponte, S. (2014). Multinational firms and the management of global networks: Insights from global value chain studies. In T. Pedersen, M. Venzin, T. M. Devinney, \& L. Tihanyi (Eds.). Orchestration of the global network organization (Vol. 27, pp. 463-486). Bingley: Emerald Group Publishing Limited.

De Marchi, V., Giuliani, E., \& Rabellotti, R. (2017). Do global value chains offer developing countries learning and innovation opportunities? European Journal of Development Research, 30(3), 389-407.

Deleuze, G.. \& Guattari, F. (2004) A thousands plateaus. London: Continuum.

DiMaggio, P. J., \& Powell, W. W. (1991). Introduction. In W. W. Powell, \& P. J. DiMaggio (Eds). The New Institutionalism in Organizational Analysis (pp. 1-38). London and Chicago: The University of Chicago Press.

Dunning, J. H. (1980). Toward an eclectic theory of international production: Some empirical tests. Journal of International Business Studies, 11(1), 9-31.

Dunning, J. H. (1988). The eclectic paradigm of international production - a restatement and some possible extensions. Journal of International Business Studies, 19(1), 1-31.

Dunning, J. H. (1995). Reappraising the eclectic paradigm in an age of alliance capitalism. Journal of International Business Studies, 26(3), 461-491.
Dunning, J. H. (1998). Location and the multinational enterprise: A neglected factor? Journal of International Business Studies, 29(1), 45-66.

Dyer, J., \& Singh, H. (1998). The relational view: Cooperative strategy and sources of interorganizational competitive advantage. Academy of Management Review, 23(4), 660-679.

Freeman, L. C. (1978). Centrality in social networks conceptual clarification. Social Networks, 1(3), 215-239.

Frohlich, M., \& Westbrook, R. (2001). Arcs of integration: An international study of supply chain strategies. Journal of Operations Management, 19(2), 185-200.

Gereffi, G. (1999). International trade and industrial upgrading in the apparel commodity chain. Journal of International Economics, 48(1), 37-70.

Gereffi, G., Humphrey, J. \& Sturgeon, T. (2005). The governance of global value chains. Review of International Political Economy, 12(1), 78-104.

Gereffi, G., \& Lee, J. (2012). Why the world suddenly cares about global supply chains. Journal of Supply Management, 48(3), 24-32.

Gereffi, G., \& Lee, J. (2016). Economic and social upgrading in global value chains and industrial clusters: Why governance matters. J Bus Ethics, 133(1), 25-38.

Grandori, A. (2006). Uncertainty, innovation and relational governance: A typology. Industry and Innovation, 13(2), 127-133.

Grant, R. (1991). The resource-based theory of competitive advantage: Implications for strategy formulation. California Management Review, 33(3), 114-135.

Gulati, R. (1998). Alliances and networks. Strategic Management Journal, 19(4), 293-317. 
Hansen, M., Nohria, N., \& Tierney, T. (1999). What's your strategy for managing knowledge? Harvard Business Review, 77(2), 106-116.

Hofstede, G. (1983). The cultural relativity of organizational practices and theories. Journal of International Business Studies, 14(2), 75-89.

Horner, R. (2017). Beyond facilitator? State roles in global value chains and global production networks. Geography Compass, 11(2), 1-13.

Horvath, L. (2001). Collaboration: The key to value creation in supply chain management. Supply Chain Management, 6(5), 205-2017.

Hoskisson, R., Eden, L., Lau, C., \& Wright, M. (2000). Strategy in emerging economies Academy of Management Journal, 43(3), 249-267.

Humphrey, J. (2014). Internalisation theory, global value chain theory and sustainability standards. In Van Tulder, R., Verbeke, A., \& Strange, R. (Eds.). International Business and Sustainable Development (pp. 91-114). Bingley, UK: Emerald Group Publishing Limited.

Humphrey, J., \& Schmitz, H. (2002). How does insertion in global value chains affect upgrading in industrial clusters? Regional Studies, 36(9), 1017-1027.

Johanson, J., \& Vahlne, J. (1977). Internationalization process of firm - model of knowledge development and increasing foreign market commitments. Journal of International Business Studies, 8(1), 23-32.

Kaplinsky, R. (2000). Globalisation and unequalisation: what can be learned from value chain analysis? Journal of Development Studies, 37(2), 117-146.

Kaplinsky, R., \& Morris, M. (2002). A handbook for value chain research. Institute of Development Studies (IDS), Brighton, United Kingdom. Retrieved from http://www.ids.ac.uk/ids/global/ pdfs/VchNov01.pdf

Kaplinsky, R., Morris, M., \& Readman, J. (2002). The globalization of product markets and immiserizing growth: Lessons from the South African furniture industry. World Development, 30(7), 1159-1177.

Keijser, C., \& Iizuka, M. (2018). Looking beyond global value chains in capacity development: The case of the IT-enabled services (ITES) Sector in South Africa. European Journal of Development Research, 30(3), 442-461.

Knight, G., \& Cavusgil, S. (2004). Innovation, organizational capabilities, and the born-global firm. Journal of International Business Studies, 35(2), 124-141.

Kogut, B., \& Singh, H. (1988). The effect of national culture on the choice of entry mode. Journal of International Business Studies, 19(3), 411-432.

Kogut, B., \& Zander, U. (1992). Knowledge of the firm. Combinative capabilities, and the replication of technology. Organization Science, 3(3), 383-397.

Kogut, B., \& Zander, U. (1993). Knowledge of the firm and the evolutionary-theory of the multinational-corporation. Journal of International Business Studies, 24(4), 625-645.

Kuhn, T. (1962). The structure of scientific revolutions. Chicago: University of Chicago Press.

Lema, R. (2014). Offshore outsourcing and innovation capabilities in the supply base: evidence from software firms in Bangalore. Int. J. Technological Learning, Innovation and Development, 7(1), 19-46.

Lorenzen, M., \& Mudambi, R. (2013). Clusters, connectivity and catch-up: Bollywood and Bangalore in the global economy. Journal of Economic Geography, 13(3), 501-534.

Manuj, I., \& Mentzer, J. (2008). Global supply chain risk management. Journal of Business Logistics, 29(1), 133-155. 
Marshall, A. (1890). Principles of economics book four: The agents of production: Land, Labour, capital and organization (Electronic version). Retrieved from https://www.marxists.org/reference/subject/ economics/marshall/bk4ch10.htm

Meyer-Stamer. J., Maggi, C., \& Seibel, S. (2004). Upgrading in the tile industry of Italy, Spain and Brazil: Insights from cluster and value chain analysis. In H Schmitz (Ed.). Local Enterprises in the Global Economy (pp. 174-99). Cheltenham: Edward Elgar.

Mintzberg, H., \& Waters, J. (1985). Of strategies, deliberate and emergent. Strategic Management Journal, 6(3), 257-272.

Morin, E. (1990). Introduction à la pensée complexe. Paris: ESF.

Morrison, A., Rabellotti, R., \& Zirulia, L. (2012). When do global pipelines enhance the diffusion of knowledge in clusters? Economic Geography, 89(1), 77-96.

Nadvi, K. (2008). Global standards, global governance and the organization of global value chains, Journal of Economic Geography, 8, 323-343.

Nadvi, K., \& Halder, G. (2005). Local clusters in global value chains: Exploring dynamic linkages between Germany and Pakistan. Entrepreneurship \& Regional Development, 17(5), 339-363.

Nahapiet, J., \& Ghoshal, S. (1998). Social capital, intellectual capital, and the organizational advantage. Academy of Management Review, 23(2), 242-266.

Narula, R., \& Wahed, M. S. (2017). The dominant presence of MNEs in Agro-Food GVCs: Implications for developing countries. In G. Mergos, \& M. Papanastassiou (Eds.). Food security and sustainability: Investment and financing along agro-food value chains (pp. 71-88). Aldershot: Palgrave Macmillan.
Nohria, N. (1992). Is a network perspective a useful way of studying organizations? In N. Nohria, \& R. Eccles (Eds.), Networks and organizations: Structure, form, and action (pp. 1-22). Boston: Harvard Business School.

Oliver, A. L., \& Ebers, M. (1998). Networking network studies: An analysis of conceptual configurations in the study of inter-organizational relationships. Organization Studies, 19(4), 549-583.

Organization for Economic Cooperation and Development, World Trade Organization, \& World Bank Group (2014). Global Value Chains: Challenges, Opportunities, and Implications for Policy. Report prepared for submission to the G20 Trade Ministers Meeting Sydney, Australia, 19 July. Retrieved from https://www.oecd.org/tad/ gvc_report_g20_july_2014.pdf

Oviatt, B., \& McDougall, P. (1994). Toward a theory of international new ventures. Journal of International Business Studies, 25(1), 45-64.

Parkhe, A. (1991). Interfirm diversity, organizational learning, and longevity in global strategic alliances. Journal of International Business Studies, 22(4), 579-601.

Parrilli, M. D., Nadvi, K., \& Yeung, H. W.C. (2013). Local and regional development in global value chains, production networks and innovation networks: A comparative review and the challenges for future research. European Planning Studies, 21(7), 967-988.

Penrose, E. T. (1959). The theory of the growth of the firm. Oxford University Press: New York.

Perks, H., Kowalkowski, C., Witell, L., \& Gustafsson, A. (2017). Network orchestration for value platform development. Industrial Marketing Management, 67, 106-121.

Pietrobelli, C., \& Staritz, C. (2018). Upgrading, interactive learning, and innovation systems in value chain interventions. European Journal of Development Research, 30(3), 557-574. 
Popper, K., \& Hansen, T. (Eds.). (2014). The two fundamental problems of the theory of Knowledge. Abingdon-on-Thames: Routledge.

Porter, M. E. (1985). Competitive advantage: Creating and sustaining superior performance. New York: Free Press.

Porter, M. E. (1991). Towards a dynamic theory of strategy. Strategic Management Journal, $12(2$ S), 95-117.

Porter, M. E. (2001). Strategy and the internet. Harvard Business Review, 79(3), 62-78.

Porter, M. E., \& Kramer, M. (2006). Strategy \& society: The link between competitive advantage and corporate social responsibility. Harvard Business Review, 84(12), 78-92.

Portes, A. (1998). Social capital: Its origins and applications in modern sociology. Annual Review of Sociology, 24, 1-24.

Powell, W. W., Koput, K. W., \& Smith-Doerr, L. (1996). Interorganizational collaboration and the locus of innovation: Networks of learning in biotechnology. Administrative Science Quarterly, 41(1), 116-145.

Rudberg, M., \& Ollager, J. (2003). Manufacturing networks and supply chains: An operation strategy perspective. Omega, 31(1), 29-39.

Rugman, A., \& Verbeke, A. (2004). A perspective on regional and global strategies of multinational enterprises. Journal of International Business Studies, 35(1), 3-18.

Rusbult, C., \& Arriaga, X. (1997). Interdependence theory. In S. Duck (Ed.). Handbook of personal relationship: Theory, research and interventions (pp. 221-250). London: John Wiley \& Sons.

Sako, M., \& Zylberberg, E. (2017). Supplier strategy in global value chains: Shaping governance and profiting from upgrading. Socio-Economic Review, 1 - 21. doi: https://doi.org/10.1093/ ser/mwx049
Saliola, F., \& Zanfei, A. (2009). Multinational firms, global value chains and the organization of knowledge transfer. Research Policy, 38(2), 369-381.

Strange, R., \& Humphrey, J. (2018). What lies between market and hierarchy? Insights from internalization theory and global value chain theory. Journal of International Business Studies. doi: http://dx.doi.org/10.1057/s41267-0180186-0

Sturgeon, T., Van Biesebroeck, J., \& Gereff, G. (2008). Value chains, networks and clusters: reframing the global automotive industry. Journal of Economic Geography, 8(3), 297-321.

Tajoli, L. \& Felice, G. (2018). Global Value Chains Participation and Knowledge Spillovers in Developed and Developing Countries: An Empirical Investigation. European Journal of Development Research, 30(3), 505-532.

Teece, D. (2010). Business models, business strategy and innovation. Long Range Planning, 43(2-3), 172-194.

Teece, D. J., Pisano, G., \& Shuen, A (1997). Dynamic capabilities and strategic management. Strategic Management Journal, 18(7), 509-533.

Todeva, E. (2006). Business Networks: Strategy and Structure. New York: Taylor \& Francis.

Todeva, E., \& Rakhmatullin, R. (2016a). Industry global value chains, connectivity and regional smart specialisation in Europe. An Overview of Theoretical Approaches and Mapping Methodologies (JRC Science for Policy Report, European Union, EUR 28086 EN). Retrieved from http:// s3platform.jrc.ec.europa.eu/documents/20182/154989/ JRC102801_lfna28086enn.pdf/04c2d91c-1e88-458da61c-4a5a12b42653

Todeva, E., \& Rakhmatullin, R. (2016b). Global value chains mapping: Methodology and cases for policy makers. (JRC Science for Policy Report, 
European Union, EUR 28085 EN). Retrieved from http://s3platform.jrc.ec.europa.eu/-/global-valuechains-mapping-methodology-and-cases-for-policymakers-thematic-work-on-value-chain-mapping-inthe-context-of-smart-specialisation?inheritRedirect=true

Tsai, W., \& Ghoshal, S. (1998). Social capital and value creation: The role of intrafirm networks. The Academy of Management Journal, 41(4), 464-476.

United Nations Conference on Trade and Development (2013). World Investment Report 2013: Global Value Chains: Investment and Trade for Development, Geneva and New York: United Nations Publication, 1-264, Retrieved from: http://unctad.org/en/publicationslibrary/ diae2013d1_en.pdf

United Nations Industrial Development Organization (2009). Industrial Development Report. Retrieved from https://www.unido.org/sites/ default/files/2009-02/IDR_2009_print_0.PDF

United Nations (2015). Transforming our World: The 2030 Agenda for Sustainable Development.
Retrieved from https://sustainabledevelopment. un.org/content/documents/21252030\%20 Agenda\% 20 for \% $20 \mathrm{Sustainable \% 20}$ Development\%20web.pdf

Uzzi, B. (1996). The Sources and Consequences of Embeddedness for the Economic Performance of Organizations: The Network Effect. American Sociological Review, 61(4), 674-698.

Uzzi, B. (1997). Social structure and competition in interfirm networks: The paradox of embeddedness. Administrative Science Quarterly, 42(1), 35-67.

Verbeke, A., Kano, L., \& Yuan, W. (2016). Inside the regional multinationals: A new value chain perspective on subsidiary capabilities. International Business Review, 25(3), 785-793.

Williamson, O. E. (1979). Transaction-Cost Economics: The Governance of Contractual Relations. Journal of Law and Economics, 22(2), 233-261 
Supporting Agencies: The authors acknowledge the support of CAPES, FAPESP, and Sylff - The Ryoichi Sasakawa Young Leaders Fellowship Fund.

\section{About the Authors:}

1. John Humphrey, Phd, University of Sussex Business School, Brighton BN1 9SL, UK.

Email: humphrey041@gmail.com

ORCID

(iD) 0000-0001-8647-3607

2. Emanuela Todeva, Phd,St. Mary's University Twickenham London, The School of Management and Social Sciences, Twickenham TW1 4SX UK.

E-mail: E.Todeva@bcned.co.uk

ORCID

(iD 0000-0003-3494-1303

3. Eduardo Armando, Pós-Doctoral, University of Surrey, Guildford, UK. E-mail: earmando@terra.com.br ORCID

(iD 0000-0002-4576-1028

4. Ernesto Giglio, Pós-Doctoral, Universidade Federal de Lavras, Lavras, Mg, Brazil.

E-mail: ernesto.giglio@gmail.com

ORCID

(iD)0000-0001-6193-1421

\section{Contribution of each author}

Each author should take responsibility for at least one component of the paper. If the article is approved for publication, the authors should indicate in the diagram below, what was the contribution of each.

\begin{tabular}{lcccc}
\hline Contribution & $\begin{array}{c}\text { John } \\
\text { Humphrey }\end{array}$ & $\begin{array}{c}\text { Emanuela } \\
\text { Todeva }\end{array}$ & $\begin{array}{c}\text { Eduardo } \\
\text { Armando }\end{array}$ & $\begin{array}{c}\text { Ernesto } \\
\text { Giglio }\end{array}$ \\
\hline 1. Definition of research problem & $\sqrt{ }$ & $\sqrt{ }$ & $\sqrt{ }$ & $\sqrt{ }$ \\
2. Development of hypotheses or research questions (empirical & $\sqrt{ }$ & $\sqrt{ }$ & \\
studies) & $\sqrt{ }$ & $\sqrt{ }$ & & $\sqrt{ }$ \\
3. Development of theoretical propositions (theoretical work) & $\sqrt{ }$ & $\sqrt{ }$ & $\sqrt{ }$ \\
4. Theoretical foundation/Literature review & & & $\sqrt{ }$ \\
5. Definition of methodological procedures & & & \\
6. Data collection & & & $\sqrt{ }$ \\
7. Statistical analysis & & & $\sqrt{ }$ \\
8. Analysis and interpretation of data & $\sqrt{ }$ & $\sqrt{ }$ & $\sqrt{ }$ \\
9. Critical revision of the manuscript & $\sqrt{ }$ & & \\
10. Manuscript writing & & & & \\
11. Other (please specify which) & & & & \\
\hline
\end{tabular}

This information will be available in publications as an end notal in accordance with the criteria, policies and procedures for admission and permanence of scientific journals in SciELO Brazil Collection.

\section{Erratum}

Where was written:

"Review of Business Management, São Paulo, v.21, n.4, p.607-627, oct/dec. 2019.”

Now read:

“Rev. Bras. Gest. Neg. São Paulo v.21, Special Issue. 2019 p. 607-627” 